\title{
The role of multidetector computed tomography of the iliac crest in forensic age estimation
}

\section{Adli yaş tayininde illiyak krestin çok kesitlii billgisayarlı tomografi ile değerlendirilmesi}

Eda Albayrak

\section{Department of Radiology, Gaziosmanpasa University, Medical Faculty, Tokat, Turkey}

Corresponding author: Eda Albayrak, Department of Radiology, Gaziosmanpasa University, Medical Faculty, Tokat, Turkey

E-mail:edalbayrak1@hotmail.com

Received/Accepted: June 18, 2017 / August 09, 2017

Conflict of interest: There is not a conflict of interest.

\section{SUMMARY}

Objective: The aim of the present study is to evaluate the iliac bone for skeletal age assessment and to determine whether Schmeling methods are applicable to the evaluation of iliac crest maturation by multidetector computed tomography (MDCT).

Method: 551 individuals ranginig in age 10-30 years who previously underwent abdominal CT examinations at various occasions in our clinic. At 5-stage method; criteria for stage 4 are that the apophyseal scar is seen as a unsharp image, or appears as an indistinct, shallow, thin notch and criteria for stage 5 are apophyseal cartilage fully ossified, apophyseal scar no longer visible.

Results: Based on the 5-stage method, the earliest ages for stage 2 are at 11.5 years in boys and 11.6 years in girls; for stage 3, 14.3 in boys and13.4 years in girls; for stage 4, 17.4 years in boys and 16.5 years in girls; for stage 5,18 years for both sexes.

Conclusion: Although the earliest age of last stage was 17 according to the 4-stage method in previous studies, the earliest age of the 5-stage method was determined to be 18 according to the the present study. These results show that the 5staging system may be more advantageous than the 4-staging system in order to determine the 18-year age limit in forensic age assessment using the iliac crest.

Keywords: Iliac apophysis, multidetector computed tomography, staging, age estimation, forensic medicine.

\section{ÖZET}

Amaç: Bu çalışmanın amacı adli kemik yaşı tayininde iliyak krestin çok kesitli bilgisayarlı tomografi (ÇKBT) ile değerlendirilmesi ve kemik yaşı tayininde beşli derecelendirme sistemi olarak kullanılan Schmeling Metodu'nun, ÇKBT eşliğinde iliyak kreste uygulanabilirliğinin araştırılmasıdır.

Yöntem: Kliniğimizde daha önce çeşitli sebeplerle elde edilen 10-30 yaşları arasındaki 551 bireye ait alt abdomen bilgisayarlı tomografi tetkiki değerlendirildi. Beşli evreleme sistemine göre evre 4'de apofizyal skar fluluk şeklinde ve belli belirsiz, sı̆̆ ince bir çentik şeklinde izlenmekte iken evre 5'te ossifikasyon tamamlanmış olup, skar hiçbir kesitte izlenmemekteydi.

Bulgular: En erken görülme yaşları evre 2'de, erkeklerde 11.5, k1zlarda 11.6, evre 3'te erkeklerde 14.3 k1zlarda 13.4, evre 4'te erkeklerde 17.4, kılarda 16.5 ve evre 5'te her iki cinsiyet için 18 olarak bulunmuştur.

Sonuç: Önceki çalışmalarda illiyak krest için kullanılan dörtlü evreleme sistemine göre son evrenin en erken görülme yaşı 17 olmasına karşın, mevcut çalışmada beşli evreleme sistemine göre 5. evrenin her iki cinsiyette en erken görülme yaşı 18 olarak belirlenmiştir ve elde edilen bulgular, iliyak kemik ile adli yaş tayininde 18 yaş sınırını belirlemek amacıyla beşli evreleme sisteminin, dörtlü evreleme sistemine göre daha avantajli olabileceğini göstermektedir.

Anahtar sözcükler: İliak apofiz, çok kesitli bilgisayarlı tomografi, evreleme, yaş tahmini, adli tıp. 


\section{INTRODUCTION}

Age estimation in living individuals has gained increasing importance in radiology and forensic medicine. Estimation of the true age of an individual is critical for precise management of affairs related to refugees, asylum-seekers, immigrants, victims of human smuggling and adopted children ${ }^{1,2}$. Moreover, in forensic practice when a person is accused of a crime, knowledge on his/her age would determine whether he/she has criminal responsibility and whether he/she will be judged according to the adult criminal justice system or the juvenile justice system ${ }^{3}$.

The Atlas of Gök, which was formed by adapting G-P atlas by Şemsi Gök and his colleagues in our country, is frequently used by forensic age estimation $^{4}$. However, with an anthropometric study of individuals, there is no widely accepted age dating technique on Turkish people ${ }^{5-8}$. Generally it is known that population records in some regions in Turkey are not timely and accurate. As a consequence, sometimes newborn children can be recorded in the population a few years later, and sometimes the pre-deceased child's identity information is used for a newborn child. In such cases, the records of these people differ from their actual ages and influential records. Problems arise when immigration, inheritance incidents, judicial incidents, concealment of age or use of false identity are required during the process of age limitations (sports clubs, pensions etc.) ${ }^{9}$.Our legal legislation also distinguishes between criminal and legal aspects for the ages, and classifies them according to man and woman. It is especially important to determine whether the 7,12, 15 and 18 nci ages have been completed ${ }^{10}$.

For forensic age assessment, the Study Group on Forensic Age Diagnostics (AGFAD) recommends radiological evaluation of the left hand and teeth, or the clavicle if hand ossification is complete ${ }^{11}$. In addition to clavicle and hand radiograms, iliac crest apophysis facilitates skeletal age estimation due to the relatively slow maturation of the iliac crest $\mathrm{t}^{12,13}$. In prior studies, direct radiograms ${ }^{14-16}$, ultrasonography ${ }^{17,18}$, magnetic resonance imaging (MRI) [19] and computed tomography (CT) ${ }^{20-22}$ have been used for evaluation of the iliac bone. However, these studies have used different skeletal age assessment methods, and no standard method has been established.

Although CT is associated with greater radiation exposure, it is superior to direct radiogram due to its multi-slice and multi-planar imaging capacity and the lack of superimpositions. Nevertheless, because of the high radiation exposure, $\mathrm{CT}$ should only be used in cases where direct radiograms are insufficient ${ }^{21-24}$. Although there are many studies on evaluation of the clavicular joint by $\mathrm{CT}^{25-27}$, and this is a widely accepted method for skeletal age assessment, few studies have addressed evaluation of the iliac bone using CTfor forensic age estimation ${ }^{20-22}$.

Several staging systems have been developed for assessment of ossification in medial clavicular epiphysis, including the 4-stage medial clavicular method developed by Kreitner et al. ${ }^{28,29}$, the 5stage method by Schmeling et al. ${ }^{30}$. Although the 4-stage method was used with some modifications, the 5-stage method was not used for the analysis of iliac crest in prior studies. The aim of the present study is to evaluate the iliac bone for skeletal age assessment using multidetector computed tomography (MDCT) and to compare the results with prior reports in the literature. We will also determine whether Schmeling methods are applicable to the evaluation of iliac crest maturation by MDCT.

\section{METHODS}

The retrospective study protocol was reviewed and approved by the local ethics committee according to the World Medical Association Declaration of Helsinki and written informed consent was waived due to the retrospective nature of the study. The study included 708 individuals ranging in age from 10-30 years who underwent abdominal CT examinations in our clinic between 2013 and 2016 for a variety of indications including trauma, unexplained abdominal pain, and intra-abdominal abscess. Those patients who were diagnosed with a metabolic disease that could cause impaired skeletal development, a pathology localized to iliac crest that could intervene with evaluation of iliac crest apophysis such as operative material, fracture or mass lesion, or whose CT sections could not be properly evaluated due to motion artifacts were excluded from the study.

All CT examinations were performed at 2- or 8slice MDCT scanners (Somatom Sprit; Siemens, Erlangen, Germany and LightSpeed Ultra; GE, Milwaukee, USA) with patient lying in supine position. Axial consecutive sections of $2,5 \mathrm{~mm}$ slice thickness were obtained by abdominal MDCT with $5 \mathrm{~mm}$ collimation, at $120-130 \mathrm{kVp}$ and automatic tube modulation, at 60-220 mA. 
Analysis of the images was carried out using a computer monitor with the Picture Archiving and Communication System Workstation (PACS) (GE Healthcare, Barrington, IL). One radiologist with at least 12 years of experience evaluated all images in separate abdomen window (window width, 340$350 \mathrm{HU}$, window level, 20-40 HU). The radiologist was blinded to the patient's age. In order to assess intra-observer agreement, the same radiologist reevaluated the same images one month later without notice of the previous evaluation findings.

The data was evaluated using the five-stage classification system described by Schmeling et al. ${ }^{30}$. These stages are as follows:
Stage 1: Ossification center not ossified (Figure 1).

Stage 2: Ossification center ossified, apophyseal cartilage not ossified (Figure 2).

Stage 3: Apophyseal cartilage partly ossified (Figure 3).

Stage 4: Apophyseal cartilage fully ossified, apophyseal scar is visible (Figure 4).

Stage 5: Apophyseal cartilage fully ossified, apophyseal scar no longer visible (Figure 5).

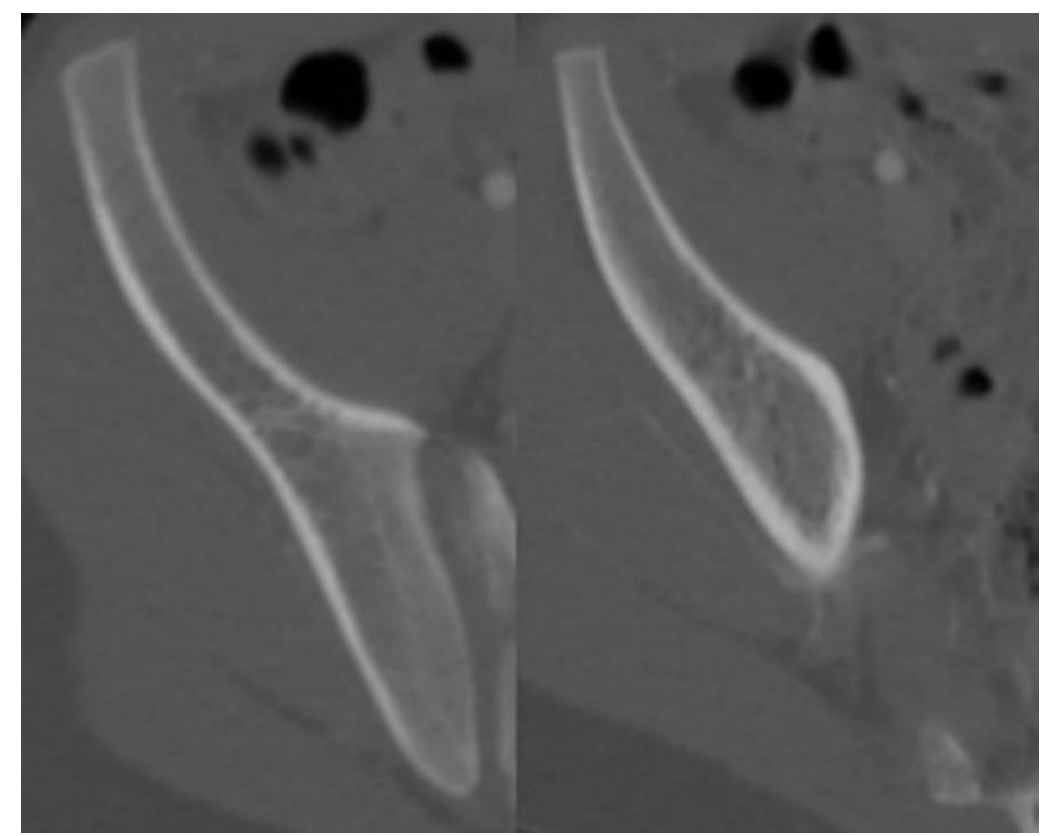

Figure 1: In axial CT sections of a 10 year-old girl, the right iliac ossification center is not yet developed (Stage 1).



Figure 2: In axial CT sections of a 13 year-old girl at stage 2, the right iliac apophyseal ossification center can be observed but ossification has not started yet (Stage 2). 


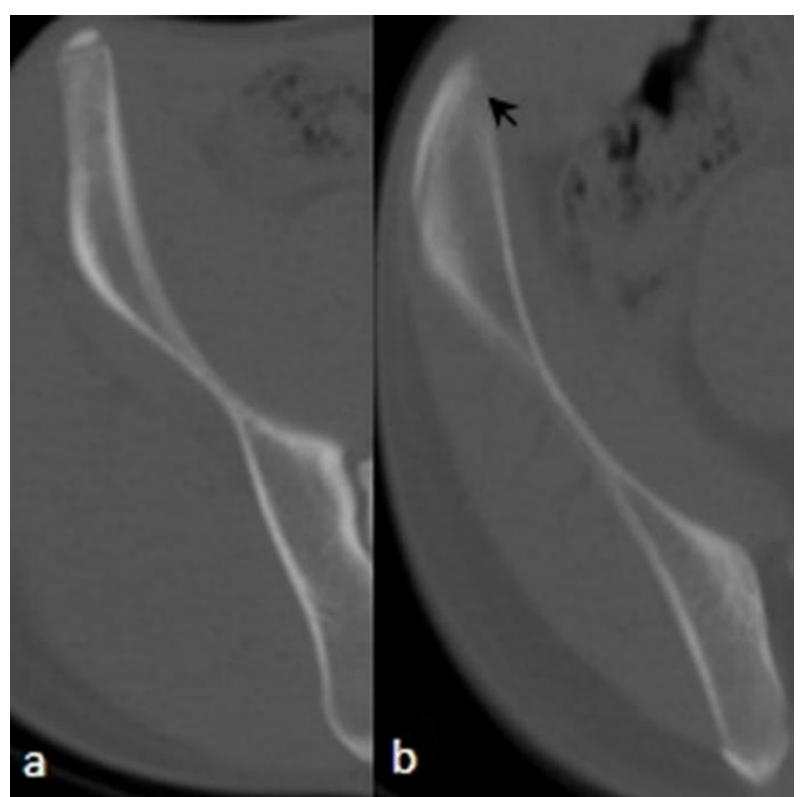

Figure 3: In axial CT sections at stage 3, the fusion between the iliac apophysis and the iliac bone on the right side is partly observed (b) (black arrow)

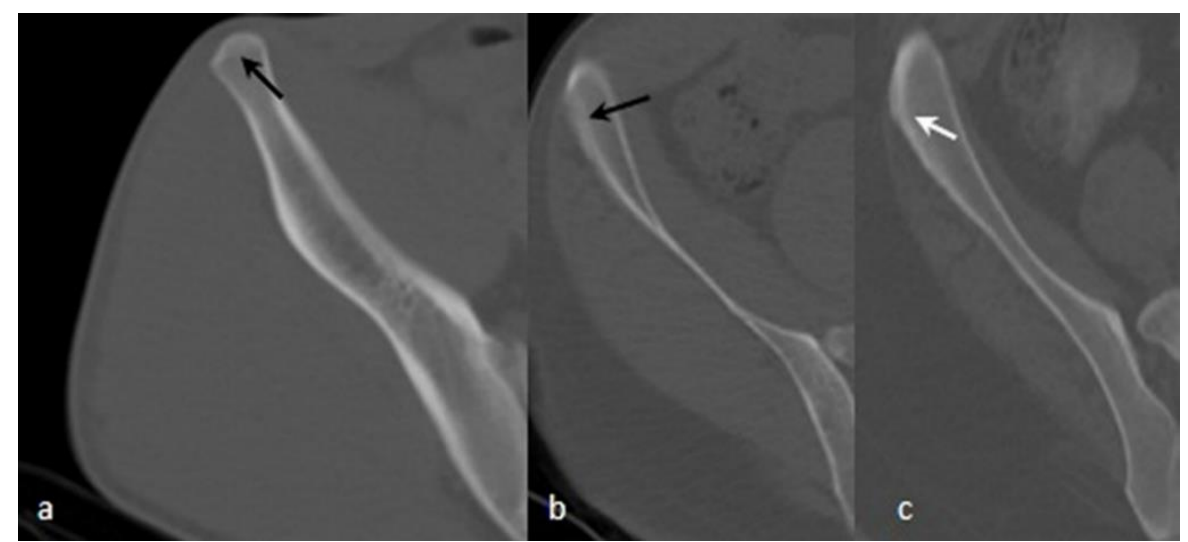

Figure 4: At stage 4, in CT sections obtained from three different patients, the epiphyseal scar (a,b) is seen as a unsharp image (black arrows), or (c) appears as an indistinct, shallow, thin notch (white arrow).

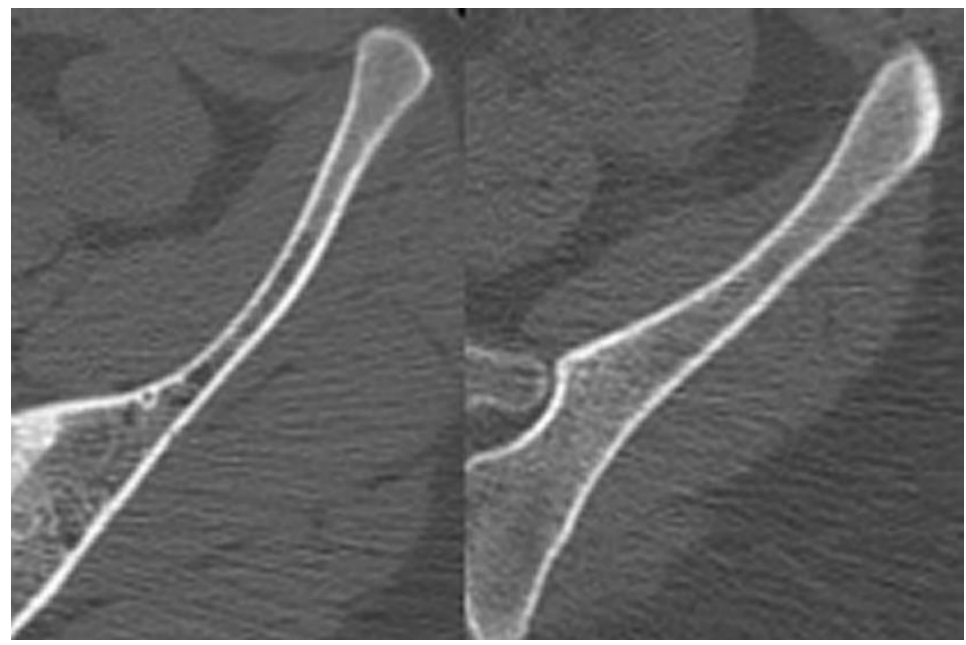

Figure 5: In axial CT sections of a 28 year-old male at stage 5, the ossification between the iliac apophysis and the iliac bone is complete, and no unsharp images or indistinct, shallow, thin notches are observed in any of the sections. 
Ossification stages were determined for both the right and the left pelvic sides. All axial sections that included the iliac crest in the examination plane were thoroughly reviewed and applied coronal and sagittal reformats when there was an uncertainty. As a result, we assessed whether there was contact between the ilium and apophysis, and if present, the degree of the contact. Patients who exhibited the absence of fusion between the iliac bone apophysis and the iliac bone were designated stage 2 , whereas patients who showed fusion in any of the sections were designated stage 3 . The apophyseal scar is seen as a unsharp image, or appears as an indistinct, shallow, thin notch on stage 4, whereas the ossification between the iliac apophysis and the iliac bone is complete, and no unsharp images or indistinct, shallow, thin notches are observed in any of the sections on stage 5 .

Descriptive analyses were performed to provide information on general characteristics of the study population. The results are presented as the minimum and maximum values, the means and standard deviation, lower and upper quartiles, and median values. The kappa statistic was determined for intra-observer agreement, the agreement beyond that which would be expected due to chance. The kappa statistics was used also to determine the differences between left and right sides of the pelvis. The criteria of Landis and Koch was used for the interpretation of the kappa values. A p-value $<0.05$ was considered significant. Analyses were performed using SPSS 19 (IBM SPSS Statistics 19, SPSS inc. an IBM Co., Somers, NY).

\section{RESULTS}

After applying all exclusion criteria, a total of 551 individuals (281 female, 270 male) was included in the study. Table 1 shows the distribution of individuals according to age and sex.

Table1. General distribution of age and gender

\begin{tabular}{lccccccccc}
\hline $\begin{array}{l}\text { Age } \\
\text { (years) }\end{array}$ & n & Column \% & Row \% & n & Column \% & Row \% & n & Column \% & Row \% \\
\hline 10 & 14 & 5 & 63.6 & 8 & 3 & 36.4 & 22 & 4 & 100 \\
11 & 14 & 5 & 66.7 & 7 & 2.6 & 33.3 & 21 & 3.8 & 100 \\
12 & 21 & 7.5 & 60 & 14 & 5.2 & 40 & 35 & 6.4 & 100 \\
13 & 23 & 8.2 & 65.7 & 12 & 4.4 & 34.3 & 35 & 6.4 & 100 \\
14 & 29 & 10.3 & 56.9 & 22 & 8.1 & 43.1 & 51 & 9.3 & 100 \\
15 & 28 & 10 & 48.3 & 30 & 11.1 & 51.7 & 58 & 10.5 & 100 \\
16 & 24 & 8.5 & 38.7 & 38 & 14.1 & 61.3 & 62 & 11.3 & 100 \\
17 & 27 & 9.6 & 45.8 & 32 & 11.9 & 54.2 & 59 & 10.7 & 100 \\
18 & 23 & 8.2 & 37.1 & 39 & 14.4 & 62.9 & 62 & 11.3 & 100 \\
19 & 14 & 5 & 38.9 & 22 & 8.1 & 61.1 & 36 & 6.5 & 100 \\
20 & 19 & 6.8 & 52.8 & 17 & 6.3 & 47.2 & 36 & 6.5 & 100 \\
21 & 7 & 2.5 & 70 & 3 & 1.1 & 30 & 10 & 1.8 & 100 \\
22 & 5 & 1.8 & 62.5 & 3 & 1.1 & 37.5 & 8 & 1.5 & 100 \\
23 & 2 & 0.7 & 50 & 2 & 0.7 & 50 & 4 & 0.7 & 100 \\
24 & 3 & 1.1 & 75 & 1 & 0.4 & 25 & 4 & 0.7 & 100 \\
25 & 5 & 1.8 & 55.6 & 4 & 1.5 & 44.4 & 9 & 1.6 & 100 \\
26 & 6 & 2.1 & 54.5 & 5 & 1.9 & 45.5 & 11 & 2 & 100 \\
27 & 3 & 1.1 & 100 & 0 & 0 & 0 & 3 & 0.5 & 100 \\
28 & 4 & 1.4 & 44.4 & 5 & 1.9 & 55.6 & 9 & 1.6 & 100 \\
29 & 7 & 2.5 & 77.8 & 2 & 0.7 & 22.2 & 9 & 1.6 & 100 \\
30 & 3 & 1.1 & 42.9 & 4 & 1.5 & 57.1 & 7 & 1.3 & 100 \\
\hline Total & 281 & 100 & 51 & 270 & 100 & 49 & 551 & 100 & 100 \\
\hline
\end{tabular}

Table 2 presents the minimum, maximum, mean \pm standard deviation, $95 \%$ confidence interval, median for each sex. No significant sex-related differences are observed for the all stages. The earliest appearance for stage 2 is at 11.50 years in boys and 11,67 in girls; for stage 3, 13.42 years in girls and 14.33 in boys; for stage $4,16.58$ years in girls and 17.42 in boys and for stage 5, 18 years for both sexes and both pelvic sides. 
Table 2. Statistical parameters (expressed in years)

\begin{tabular}{|c|c|c|c|c|c|c|}
\hline Stage & Gender & $\mathbf{n}$ & Min-Max & Mean \pm SD & $95 \%$ CI mean age & Median \\
\hline \multicolumn{7}{|l|}{$\begin{array}{l}\text { Right } \\
\text { pelvis }\end{array}$} \\
\hline \multirow[t]{2}{*}{1} & Female & 48 & $10-15.42$ & $11.44 \pm 1.35$ & $11.06-11.82$ & 11.25 \\
\hline & Male & 44 & $10-15.42$ & $12.44 \pm 1.68$ & $11.94-12.93$ & 12.33 \\
\hline \multirow[t]{2}{*}{2} & Female & 61 & $11.67-18$ & $13.72 \pm 1.22$ & $13.42-14.03$ & 13.50 \\
\hline & Male & 58 & $11.5-18$ & $14.71 \pm 1.5$ & $14.32-15.09$ & 14.83 \\
\hline \multirow[t]{2}{*}{3} & Female & 85 & $13.42-20$ & $16.35 \pm 1.49$ & $16.03-16.67$ & 16.00 \\
\hline & Male & 84 & $14.33-21$ & $16.88 \pm 1.34$ & $16.59-17.16$ & 17.00 \\
\hline \multirow[t]{2}{*}{4} & Female & 38 & $16.58-29$ & $20.35 \pm 3.61$ & $19.2-21.5$ & 19.00 \\
\hline & Male & 49 & $17.42-29$ & $19.69 \pm 2.67$ & $18.95-20.44$ & 19.00 \\
\hline \multirow[t]{2}{*}{5} & Female & 49 & $18-30$ & $23.71 \pm 3.66$ & $22.68-24.73$ & 24.00 \\
\hline & Male & 35 & $18-30$ & $23.19 \pm 4.32$ & $21.76-24.62$ & 22.00 \\
\hline \multirow[t]{2}{*}{ Total } & Female & 281 & $10-30$ & $16.77 \pm 4.74$ & $16.21-17.32$ & 16.00 \\
\hline & Male & 270 & $10-30$ & $17.02 \pm 3.99$ & $16.54-17.49$ & 17.00 \\
\hline \multicolumn{7}{|c|}{ Left pelvis } \\
\hline \multirow[t]{2}{*}{1} & Female & 49 & $10-15.42$ & $11.44 \pm 1.33$ & $11.07-11.81$ & 11.25 \\
\hline & Male & 46 & $10-15.42$ & $12.4 \pm 1.65$ & $11.92-12.88$ & 12.33 \\
\hline \multirow[t]{2}{*}{2} & Female & 60 & $11.67-18$ & $13.76 \pm 1.2$ & $13.45-14.06$ & 13.58 \\
\hline & Male & 56 & $11.75-18$ & $14.82 \pm 1.39$ & $14.46-15.19$ & 14.92 \\
\hline \multirow[t]{2}{*}{3} & Female & 84 & $13.42-20$ & $16.34 \pm 1.5$ & $16.02-16.66$ & 16.00 \\
\hline & Male & 85 & $14.33-21$ & $16.89 \pm 1.34$ & $16.6-17.17$ & 17.00 \\
\hline \multirow[t]{2}{*}{4} & Female & 39 & $16.58-29$ & $20.26 \pm 3.61$ & $19.13-21.39$ & 19.00 \\
\hline & Male & 48 & $17.42-29$ & $19.73 \pm 2.69$ & $18.97-20.49$ & 19.00 \\
\hline \multirow[t]{2}{*}{5} & Female & 49 & $18-30$ & $23.71 \pm 3.66$ & $22.68-24.73$ & 24.00 \\
\hline & Male & 35 & $18-30$ & $23.19 \pm 4.32$ & $21.76-24.62$ & 22.00 \\
\hline \multirow[t]{2}{*}{ Total } & Female & 281 & $10-30$ & $16.77 \pm 4.74$ & $16.21-17.32$ & 16.00 \\
\hline & Male & 270 & $10-30$ & $17.02 \pm 3.99$ & $16.54-17.49$ & 17.00 \\
\hline
\end{tabular}

Non-significant developmental differences between the left and the right pelvic sides were observed in 7 cases.
Intra-observer reliabilities showed very good agreement. Table 3 presents Cohen's kappa values for intra-observer agreement.

Table 3. Intraobserver agreement

\begin{tabular}{lc}
\hline & Intra-observer agrement \\
\hline Number & 551 \\
Agreement rate & $98.7 \%$ \\
Kappa value (k) & 0.985 \\
$\mathrm{p}$ & $<0.001$ \\
\hline
\end{tabular}

\section{DISCUSSION}

Several previous studies have reported on the evaluation of iliac crest apophysis for skeletal age assessment using various radiological methods. These studies have also used several different staging methods, and no standard method has been established. Schmidt et al..$^{18}$ used a 4-stage method to classify ultrasonography images 28,29 , and reported that stage 4 occurs at age 17 years or older in both sexes. Wittschieber et al. ${ }^{19}$ conducted an MRI study in soccer players using 4-stage method and observed both stage 3 and 4 in individuals between 18-22 years of age. The researchers emphasized that further studies including both sexes and broader populations are necessary for more accurate assessment. 
Several studies have evaluated the iliac crest using conventional radiograms. Wittschieber et al. ${ }^{14}$ used the Risser staging system modified for French and American populations ${ }^{31-35}$, and reported that the earliest age for stage 4 was 14 . They found that the earliest age for stage 5 in both sexes was 14 according to the American modification, while according to the French system, the earliest age for stage 5 was 16 in girls and 17 in boys. The 5 -stage method used in that study is different from the one that is used in the present study. According to the Risser staging system, stage 5 denotes fusion of the iliac crest apophysis from the commencement of the process posteromedially until completion of fusion complete fusion, whereas in the Schmeling method used in the present study, stage 5 indicates disappearance of the apophyseal scar. Different results are expected due to these methodological differences.

In another study by Wittschieber et al. ${ }^{15}$, the authors evaluated iliac apophysis with direct radiograms with 4-stage method developed by Kreitner et al. They indicated that the apophyseal scar, whose disappearance denotes stage 5 according to Schmeling method, could not be visualized in the iliac crest with conventional radiograms, and therefore they used the 4-stage method by Kreitner ${ }^{28,29}$. The authors stated that conventional radiograms might not be reliable due to projection artifacts that obscured the posterior part of iliac crest, and sectional imaging methods like $\mathrm{CT}$ and MRI could help to avoid these artifacts. In our study, owing to the sectional imaging capacity of CT, we examined the whole iliac crest using thin slices and could visualize the apophyseal scar as a thin notch or blurring at some part of the apophysis. For the first time in the literature, we applied the 5-stage method by Schmeling et al. ${ }^{30}$ to iliac crest apophysis, and found that the earliest age at stage 5 could be observed as 18 in both sexes. According to the 4-stage method ${ }^{15}, 28,29$, the upper age limit for iliac crest apophysis is 17 , whereas in the 5-stage system [30] this limit might be increased to 18 , and therefore the 5-stage method ${ }^{30}$ is advantageous in evaluation of the iliac crest for skeletal age assessment.

In a recent study researchers have evaluated iliac bone apophysis with 3D-MDCT for forensic age estimation ${ }^{20}$. The results of this study provide an overdue, cautionary note on the implications of routinely utilized imaging modalities such as plain film radiography for the evaluation of ossification status. They provide and validate a modified six stage 3D-MDCT scoring tier of ossification, demonstrating complete fusion between 17.3-19.2 and 17.1-20.1 years in males and females. Legal demarcation for age of majority (18 years) can be achieved for apophyseal fusion using the recalibrated standards. In this study stage I, II and III expressed apophyseal ossification, stage IV and $\mathrm{V}$ expressed active apophyseal union and stage VI expressed complete union. Stage VI used in this study has similar properties with stage 5 used in our study due to common trait of complet union. Because the earliest age for the last stages in both stages systems are greater than age 17, both stages systems are superior to the previous stages methods for determining whether a subject is under the age of 18 years in forensic age assessment using the iliac crest.

A prior study has evaluated iliac bone apophysis with CT for forensic age estimation with 4-stage method developed by Kreitner et al. ${ }^{21}$. In that study, the earliest ages to observe stages 2, 3 and 4 were 12,14 and 17 , respectively and the results are similar with our study for stages 2,3 and 4 . Because the aforementioned study did not aply stages 5, we could not compare the results of stage 5 used in our study.

Few anthropological studies have evaluated iliac crest apophyseal ossification ${ }^{36,37}$. Webb et al. ${ }^{36}$ used a 4-stage method in their study, and found that the earliest age at which complete fusion can be observed was 17 in boys and 18 in girls, similar to our results. Another study ${ }^{37}$ used a 3 -stage method, and the earliest age at which complete union was reported was 20 in boys and 22 in girls. There are differences between anthropological studies and our results. The discrepancies between the results may be due to different staging systems between our study and anthropological studies or socioeconomic and ethnic differences among the study populations 38,39 . Further anthropological studies in different populations are needed to understand these differences.

In comparison to conventional methods, iliac CT examination has several advantages including avoidance of superimposition caused by intestinal gas, foreign bodies, or operative materials; marked reduction of the superposition between the apophysis and iliac bone; and the ability to examine in multiplanar reconstruction. However, one disadvantage of CT is higher radiation exposure compared to plain radiography, and this makes it almost impossible to conduct prospective studies on iliac bone morphology ${ }^{40,41}$. Nonetheless, use of gonadal protection shields during pelvic scans may somewhat reduce the exposed radiation dose ${ }^{30}$. Hand and wrist radiograms, and medial clavicular joint examinations provide invaluable information for skeletal age estimation ${ }^{11,23,24}$, and in our 
opinion, the evaluation of iliac crest apophysis using CT for forensic age estimation may be used as confirmatory imaging methods aiding in the diagnosis when there is uncertainty in evaluation of the iliac bone apophysis.

Previous studies have reported that ethnic origin has no significance in skeletal development ${ }^{38}$. One study that categorized the previous studies according to the human development index (HDI) of countries has found that socioeconomic factors influence skeletal development, with poor socioeconomic conditions delaying skeletal maturation ${ }^{38,39}$. Similar to our study, the another CT study examining the iliac crest apophysis ${ }^{30}$ was conducted on a Turkish population; the study group had similar features to our study in terms of socioeconomic and ethnic status and the results of this study are similar with our study for stages 2,3 and 4.

There are some limitations of our study. Firstly, we have no data regarding intra-observer agreement as the examinations are carried out by a single researcher. However, the intra-observer agreement is excellent in our study. Secondly, the slice thickness used in our study is relatively high. Image quality is expected to increase as slice thickness decreases. On the other hand, there are few studies in the literature that evaluated iliac crest apophysis with CT; therefore, the optimum slice thickness for evaluation of iliac bone apophysis has not been clearly demonstrated yet.

\section{CONCLUSION}

Evaluation of iliac crest apophysis with CT is an easy and convenient method for skeletal age assessment, providing valuable complementary and confirmatory information to the clinician when used alongside other skeletal age assessment methods. Based on the 5-stage method by Schmeling ${ }^{30}$, we found that the earliest age observed at stage 5 was 18 years in both sexes, whereas previous studies using the 4-stage method ${ }^{28,29}$ reported that stage 4 could be observed at 17 . These results indicate that the 5-stage method 30 may be superior to the 4-stage method ${ }^{28,29}$ for determining whether a subject is under the age of 18 years in forensic age assessment using the iliac crest. Our study is a pilot study for evaluation of iliac crest with $\mathrm{CT}$ and to the best of our knowledge, for the first time in literature, we applied the Schmeling ${ }^{30}$ method to evaluate iliac crest apophysis with CT for the forensic age estimation. There is need for further studies evaluating iliac crest apophysis for skeletal age assessment using thinner slice thickness and including different socioeconomic groups.

\section{REFERENCES}

1- Serinelli S, Panebianco V, Martino M, Battisti S, Rodacki K, Marinelli E, Zaccagna F, Semelka RC, Tomei E. Accuracy of MRI skeletal age estimation for subjects 12-19. Potential use for subjects of unknown age. Int J Legal Med 2015; 129: 609-17.

2-Separated Children in Europe ProgrammeThematic Group on Age Assessment. Review of current laws, policies and practices relating to age assessment in sixteen European Countries. Available at: http://www.separated-childreneurope-

programme.org/publications/reports/Age_Assess ment_report_review_of_current_policies_and_pra ctice_in_Europe_2011

3- Schmeling A, Olze A, Reisinger W, Geserick G. Age estimation of living people undergoing criminal proceedings. Lancet 2001; 358: 89-90.

4. Baransel Isır A, Dülger HE. 1998-2005 yılları arasında Gaziantep Üniversitesi Adli Tip Anabilim Dalında raporlandırılan yaş tayini olgularının irdelenmesi. Türkiye Klinikleri Adli Tıp Dergisi 2007; 4: 1-6.

5. Koç A, Karaoğlanoğlu M, Erdoğan M, Kosecik M, Cesur Y. Assessment of bone ages: Is the Greulich-Pyle method sufficient for Turkish boys? Pediatr Int 2001; 43: 662-5.

6. Kinik E, Karaman $\mathrm{O}$, Büyükgebiz A. Determination of various parameters of sexuel maturity in adolescent boys in Ankara. Turk $\mathbf{J}$ Pediatr 1987; 29: 217-26.

7. Büyükgebiz A, Eroğlu Y, Karaman O, Kinik E. Height and weight measurements of male Turkish adolescents according to biological maturation. Acta Pediatr Jpn 1994; 36: 80-3.

8. Mayda AS, Koçoğlu G. Antropometrik değerler. In: Mayda AS, Koçoğlu G, eds; Sivas il merkezindeki ilkokul çocukları için referans antropometrik değerler. 1. Baskı. Sivas: Cumhuriyet Üniversitesi Yayınları No:79; 1999: 146.

9. Isır, Aysun Baransel. Adli Hekimlikte Yaş Tayini. In: Sermet KOÇ, Muhammet CAN, eds; Birinci Basamakta Adli Tip. 2. Baskı. İstanbul: İstanbul Tabip Odas1 yayınlar1; 2011: 222-31.

10. Sarıkardaşoğlu İ. Adli tıpta ana konular ve örneklerle rapor yazma tekniği. Anadolu Üniversitesi Yayınları No:369, Eskişehir; 1990: 22-35. 
11- Schmeling A, Grundmann C, Fuhrmann A, Kaatsch HJ, Knell B, Ramsthaler F, Reisinger W, Riepert T, Ritz-Timme S, Rösing FW, Rötzscher $\mathrm{K}$, Geserick G. Criteria for age estimation in living individuals. Int J Legal Med 2008; 122: 457-60.

12- Scoles PV, Salvagno R, Villalba K, Riew D. Relationship of iliac crest maturation to skeletal and chronologic age. J Pediatr Orthop 1988; 8: 639-44.

13- Güvener M, Korel N, Reimann F. Can the development and maturation of the pelvic bones be used to support and amplify the determination of bone age in adolescents and young adults? Rontgenpraxis 1984; 37: 264-8.

14- Wittschieber D, Schmeling A, Schmidt S, Heindel W, Pfeiffer H, Vieth V. The Risser signfor forensic age estimation in living individuals: a study of 643 pelvic radiographs. Forensic Sci Med Pathol 2013; 9: 36-43.

15- Wittschieber D, Vieth V, Domnick C, Pfeiffer $\mathrm{H}$, Schmeling A. The iliac crest in forensicage diagnostics: evaluation of the apophyseal ossification in conventional radiography. Int $\mathrm{J}$ Legal Med 2013; 127: 473-9.

16- Wittschieber D, Vieth V, Wierer T, Pfeiffer H, Schmeling A. Cameriere's approach modified for pelvic radiographs: a novel method to assess apophyseal iliac crest ossification for the purpose of forensic age diagnostics. Int J Legal Med 2013; 127: 825-9.

17- Schmidt S, Schmeling A, Zwiesigk P, Pfeiffer H, Schulz R. Sonographic evaluation of apophyseal ossification of the iliac crest in forensic age diagnostics in living individuals. Int J Legal Med 2011; 125: 271-6.

18- Schmidt S, Schiborr M, Pfeiffer H, Schmeling A, Schulz R. Sonographic examination of the apophysis of the iliac crest for forensic age estimation in living individuals. Sci Justice 2013; 53: 395-401.

19- Wittschieber D, Vieth V, Timme M, Dvorak J, Schmeling A. Magnetic resonance imaging of the iliac crest: age estimation in under 20 soccer players. Forensic Sci Med Pathol 2014; 10: 198202.

20- Lottering N, Alston-Knox CL, MacGregor DM, Izatt MT, Grant CA, Adam CJ, Gregory LS. Apophyseal ossification of the iliac crest in forensic age estimation: computed tomography standards for modern Australian subadults. J Forensic Sci 2017; 62: 292-307.
21- Ekizoglu O, Inci E, Erdil I, Hocaoglu E, Bilgili MG, Kazimoglu C. Reisoglu A, Can IO. Computed tomography evaluation of the iliac crest apophysis: age estimation in living individuals. Int $\mathrm{J}$ Legal Med 2016; 130: 1101-7.

22- Karami M, Rabiei M, Riahinezhad M. Evaluation of the pelvic apophysis with multidetector computed tomography for legal age estimation in living individuals. J Res Med Sci 2015; 20: 209-13.

23- Wittschieber D, Ottow C, Vieth V, Küppers M, Schulz R, Hassu J. Bajanowski T, Püschel K, Ramsthaler F, Pfeiffer H, Schmidt S, Schmeling A. A Projection radiography of the clavicle: still recommendable for forensic age diagnostics in living individuals? Int J Legal Med 2015; 129: 18793.

24- Brown AA, Derkyi-Kwarteng L, AmonooKuofi HS. Study on the time frame for ossification of the medial clavicular epiphyseal cartilage by Xray in Ghanaian students. Int J Morphol 2013; 31: 491-6.

25- Gurses MS, Inanir NT, Gokalp G, Fedakar R, Tobcu E, Ocakoglu G. Evaluation of age estimation in forensic medicine by examination of medial clavicular ossification from thin slice computed tomography images. Int J Legal Med 2016; 130: 1343-52.

26- Ufuk F, Agladioglu K, Karabulut N. CT evaluation of medial clavicular epiphysis as a method of bone age determination in adolescents and young adults. Diagn Interv Radiol 2016; 22: 241-6.

27- Milenkovic P, Djuric M, Milovanovic P, Djukic K, Zivkovic V, Nikolic S. The role of CT analyses of the sternal end of the clavicle and the first costal cartilage in age estimation. Int J Legal Med 2014; 128: 825-39.

28- Kreitner KF, Schweden F, Schild HH, Riepert T, Nafe B. Die computertomographisch bestimmte Ausreifung der medialen Klavikulaepiphyse - eine additive Methode zur Altersbestimmung im Adoleszentenalter und in der dritten Lebensdekade? Fortschr Röntgenstr 1997; 166: 481-6.

29- Kreitner KF, Schweden FJ, Riepert T, Nafe B, Thelen M. Bone age determination based on the study of the medial extremity of the clavicle. Eur Radiol 1998; 8: 1116-22.

30- Schmeling A, Schulz R, Reisinger W, Mühler M, Wernecke KD, Geserick G. Studies on the time frame for ossification of medial clavicular 
epiphyseal cartilage in conventional radiography. Int J Legal Med 2004; 118: 5-8.

31- Risser JC, Ferguson AB. Scoliosis: its prognosis. J Bone Joint Surg 1936; 18: 667-70.

32- Risser JC. Important practical facts in the treatment of scoliosis. Instr Course Lect 1948; 5: 248-60.

33. Risser JC. The Iliac apophysis; an invaluable sign in the management of scoliosis. Clin Orthop 1958; 11: 111-9.

34- Risser JC. Treatment of scoliosis during the past 50 years. Clin Orthop Relat Res 1966; 44: 10913.

35- Bitan FD, Veliskakis KP, Campbell BC. Differences in the Risser grading systems in the United States and France. Clin Orthop Relat Res 2005; 436: 190-5.

36- Schmeling A, Reisinger W, Loreck D, Vendura K, Markus W, Geserick G. Effects of ethnicity on skeletal maturation: consequences for forensic age estimations. Int J Legal Med 2000; 113: 253-8.

37- Meijerman L, Maat GJ, Schulz R, Schmeling A. Variables affecting the probability of complete fusion of the medial clavicular epiphysis. Int $\mathbf{J}$ Legal Med 2007; 121: 463-8.

38- Owings-Webb PA, Myers-Suchey J. Epiphyseal union of the anterior iliac crest and medial clavicle in a modern multiracial sample of American males and females. Am J Phys Anthropol 1985; 68: 457-66.

39- Coqueugniot H, Weaver TD. Brief communication: infracranial maturation in the skeletal collection from Coimbra, Portugal: new aging standards for epiphyseal union. Am J Phys Anthropol 2007; 134: 424-37.

40- Ramsthaler F, Proschek P, Betz W, Verhoff MA. How reliable are the risk estimates for X-ray examinations in forensic age estimations? A safety update. Int J Legal Med 2009; 123: 199-204.

41. Okkalides D, FotakisM. Patient effective dose resulting from radiographic examinations. $\mathrm{Br} \mathrm{J}$ Radiol 1994; 67: 564-72. 